\title{
Corrigendum: Habitual Behavior and Dopamine Cell Vulnerability in Parkinson Disease
}

OPEN ACCESS

Edited by:

Ricardo Insausti,

University of Castilla-La Mancha,

Spain

Reviewed by:

Monica Munoz-Lopez,

University of Castilla-La Mancha,

Spain

Emilio Artacho-Perula,

University of Castilla-La Mancha,

Spain

*Correspondence:

José A. Obeso

jobeso.hmcinac@hmhospitales.com

Received: 14 October 2015 Accepted: 05 November 2015 Published: 17 November 2015

Citation:

Hernández LF, Redgrave P and Obeso JA (2015) Corrigendum: Habitual Behavior and Dopamine Cell

Vulnerability in Parkinson Disease.

Front. Neuroanat. 9:146.

doi: 10.3389/fnana.2015.00146

\author{
Ledia F. Hernández ${ }^{1,2}$, Peter Redgrave ${ }^{3}$ and José A. Obeso ${ }^{1,2 *}$ \\ ${ }^{1}$ Centre for Integrative Neuroscience A.C., Fundacion HM, Hospital HM Puerta del Sur, Mostoles and CEU San Pablo \\ University, Madrid, Spain, ${ }^{2}$ Center for Networked Biomedical Research on Neurodegenerative Diseases, Institute Carlos III, \\ Madrid, Spain, ${ }^{3}$ Department of Psychology, University of Sheffield, Sheffield, UK
}

Keywords: Parkinson disease, habitual and goal-directed behavior, vulnerability, dopamine, substantia nigra pars compacta

\section{A corrigendum on}

Habitual behavior and dopamine cell vulnerability in Parkinson disease by Hernandez, L. F., Redgrave, P., and Obeso, J. A. (2015). Front. Neuroanat. 9:99. doi: 10.3389/fnana.2015.00099

Figure 1 of the article by Hernandez et al. (2015) contained a minor error, which we hereby rectify. In the original figure dorsolateral striatum (posterior putamen) is shown as part of the goal-directed loop while dorsomedial striatum (rostral putamen) is shown as part of the habitual loop. These boxes are switched. We therefore re-submit Figure 1 with the correct boxes in the middle panel.

Conflict of Interest Statement: The authors declare that the research was conducted in the absence of any commercial or financial relationships that could be construed as a potential conflict of interest.

Copyright $\odot 2015$ Hernández, Redgrave and Obeso. This is an open-access article distributed under the terms of the Creative Commons Attribution License (CC BY). The use, distribution or reproduction in other forums is permitted, provided the original author(s) or licensor are credited and that the original publication in this journal is cited, in accordance with accepted academic practice. No use, distribution or reproduction is permitted which does not comply with these terms. 


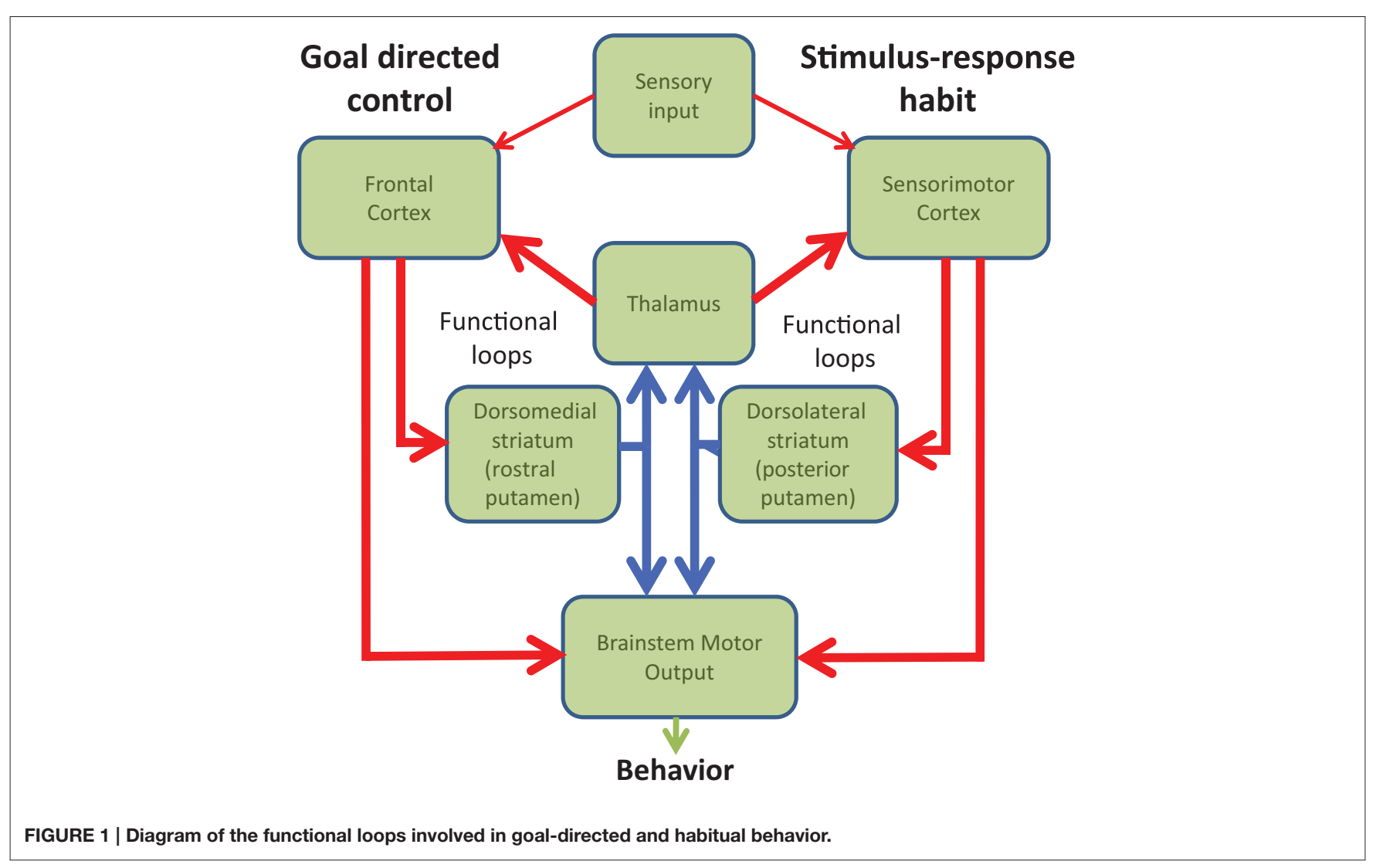

